\title{
Prevalence and genotypes of the human papillomavirus in laryngeal tissue samples of patients with laryngeal cancer from Northeastern Mexico
}

\author{
Prevalencia y genotipos del virus del papiloma humano en muestras de tejido laríngeo de \\ pacientes con cáncer de laringe del noreste de México
}

\author{
Gerardo C. Palacios-Saucedo ${ }^{*}$, José M. Vázquez-Guillén², Lydia G. Rivera-Morales², \\ Ricardo García-Cabello ${ }^{1}$, Ethel C. Sánchez-Fresno ${ }^{1}$, Martha S. Montalvo-Bañuelos ${ }^{3}$, \\ Julio C. Serna-Hernández', Silvia J. Hernández-Martínez', Edmundo E. Castelán-Maldonado', \\ Ángel Zavala-Pompa², Gustavo I. Amador-Patiño² and Cristina Rodríguez-Padilla²
}

${ }^{1}$ Health Research Division, Department of Otolaryngology and Department of Pathological Anatomy, Unidad Médica de Alta Especialidad, Hospital de Especialidades No. 25, Instituto Mexicano del Seguro Social (IMSS), Monterrey; ${ }^{2}$ Laboratory of Immunology and Virology, Faculty of Biological Sciences, Universidad Autónoma de Nuevo León, San Nicolás de los Garza; ${ }^{3}$ Department of Speech Therapy, Hospital General de Zona No. 6 , IMSS, San Nicolás de los Garza, Nuevo León, Mexico

\begin{abstract}
Background: Laryngeal cancer represents $21.7 \%$ of malignancies of the upper aerodigestive tract. The prevalence of the Human Papillomavirus (HPV) in laryngeal cancer ranges 0 to $80 \%$. Methods: We included 112 laryngeal tissue samples obtained from patients with laryngeal cancer. DNA was extracted and amplified by PCR. HPV presence and genotype were analyzed by the reverse hybridization INNO-LiPA ${ }^{\circledR}$ assay. Chi-square, Fisher's and unpaired Student $t$ tests were used. Results: Samples from 107 male (95.5\%) and 5 female patients (4.5\%) were evaluated, aged 65.3 \pm 10.1 years, 108 with smoking history (96.4\%), 9 with alcoholism history (8.0\%), and in 96 the histological diagnosis was moderately differentiated keratinizing squamous cell carcinoma (85.7\%). HPV was detected in 60 samples (53.5\%), HPV-11 in 51 (45.5\%), HPV-52 in 27 (24.1\%), HPV-16 in 9 (8.0\%), HPV-45 in 3 (2.6\%), and coinfection by more than one genotype in 31 (27.6\%). There was no difference between patients with and without HPV infection with respect to age, sex, tumor location and histology, smoking and alcoholism history $(p>0.05)$. Conclusions: The prevalence of HPV infection in laryngeal cancer was $53.5 \%$ with coinfection with more than one genotype in $27.6 \%$. The most frequent genotype was HPV-11, an oncogenic low-risk genotype, followed by HPV-52, a high-risk genotype.
\end{abstract}

Key words: Laryngeal cancer. Human papillomavirus virus. HPV. Genotype.

\section{Resumen}

Antecedentes: El cáncer de laringe representa el $21.7 \%$ de las neoplasias malignas de vías aerodigestivas superiores. La prevalencia del virus del papiloma humano (VPH) en el cáncer de laringe oscila entre el 0 y el 80\%. Método: Se incluyeron

\footnotetext{
Correspondence:

*Gerardo C. Palacios-Saucedo

Fidel Velásquez y Lincoln, $\mathrm{s} / \mathrm{n}$

Col. Nueva Morelos

C.P. 64320, Monterrey, N.L., México

Date of reception: 23-03-2018

E-mail: gerardo.palacios@gmail.com

gerardo.palacios@imss.gob.mx

Date of acceptance: 14-05-2018

DOI: $10.24875 / C I R U E . M 18000077$

0009-7411/@ 2018 Academia Mexicana de Cirugía. Published by Permanyer. This is an open access article under the terms of the CC BY-NC-ND license (http://creativecommons.org/licenses/by-nc-nd/4.0/).
} 
112 muestras de tejido laríngeo de pacientes con cáncer de laringe. Se amplificó el ADN y se analizó la presencia y el genotipo del VPH mediante hibridación reversa (INNO-LiPA ${ }^{\circledR}$ ). Se realizaron pruebas de ji cuadrada, Fisher y $t$ de Student no pareada. Resultados: Se incluyeron muestras de 107 hombres (95.5\%) y 5 mujeres (4.5\%), con una edad de $65.3 \pm 10.1$ años, con antecedente de tabaquismo 108 (96.4\%), alcoholismo 9 (8.0\%) y carcinoma epidermoide moderadamente diferenciado queratinizante 96 (85.7\%). Se identificó VPH en 60 (53.5\%), VPH-11 en 51 (45.5\%), VPH-52 en 27 (24.1\%), VPH-16 en 9 (8.0\%), VPH-45 en 3 (2.6\%) y coinfección por más de un genotipo en 31 (27.6\%). No hubo diferencia entre pacientes con y sin infección por VPH en cuanto a edad, sexo, localización, diagnóstico histopatológico, tabaquismo ni alcoholismo ( $p$ > 0.05). Conclusiones: La prevalencia de infección por VPH en el cáncer de laringe fue del 53.5\%, con coinfección por más de un genotipo en el 27.6\%. El genotipo más frecuente fue el VPH-11, tipo de bajo riesgo, seguido por el VPH-52, de alto riesgo oncogénico.

Palabras clave: Cáncer de laringe. Virus del papiloma humano. VPH. Genotipo.

\section{Introduction}

Laryngeal cancer accounts for $21.7 \%$ of malignant neoplasms of the upper aerodigestive tract, but only for $0.8 \%$ of total malignancies ${ }^{1}$. Laryngeal cancer has as main risk factors smoking and alcoholism. Information in international literature is scarce with regard to other possible risk factors, such as gastroesophageal reflux and human papillomavirus (HPV) infection ${ }^{2-4}$.

HPV is a double-stranded DNA virus whose tumor activity is mainly associated with oncoproteins $\mathrm{E} 6$ and E7. HPV genotypes are divided in those with low oncogenic risk (6, 11, 40, 42, 53, 54 and 57) and those associated with high risk $(16,18,32,35,39,45,51$, 56 and 58$)^{5}$. HPV has been identified as the cause of different squamous cell head and neck cancers, with HPV-16 being the most commonly associated with laryngeal carcinoma ${ }^{6-9}$.

In the international literature, the presence HPV has been reported in laryngeal cancer at a percentage that ranges between 0 and $80 \%^{9-17}$. In Mexico, there are three published studies concerning HPV prevalence in larynx cancer. In the first of them, 16 of 32 patient samples were HPV-positive; the second found that only 4 of 16 studied samples had HPV infection; and in the third study, only 2 out of 45 samples were HPV-positive ${ }^{9,18,19}$. In the present study, HPV prevalence and genotypes were evaluated in laryngeal tissue samples of patients with laryngeal cancer from a tertiary care medical unit of northeastern Mexico.

\section{Method}

Samples of cancer-diagnosed laryngeal tissue embedded in paraffin blocks, which were obtained by biopsy or complete resection in the otorlaringology and pathological anatomy department of a tertiary care medical unit of the city of Monterrey, located in northeastern Mexico, were collected. Samples obtained and processed in the period from 2012 to 2015, which were 112, were included. Those with extensive necrosis, histologically defined as the presence of inappropriate necrotic tissue for DNA recovery in more than $50 \%$ of the slide, samples with useless material due to inadequate histological processing due to poor fixation of the sample, cases of insufficient sample when, due to scarce sample of tissue, there was no representative neoplastic cells, and those from patients whose record was not available in the hospital archive were eliminated. Information on patient clinical characteristics, such as age, gender, history of smoking, alcohol consumption, tumor location and histopathological diagnosis was collected from medical records.

\section{DNA extraction}

Two fragments of the paraffin-embedded tissue were obtained by punch (biopsy punch). To obtain DNA, the Nucleo Spin ${ }^{\circledR}$ FFPE DNA kit was used (Macherey-Nagel, Düren, Germany). The fragments were placed in a $1.5-\mathrm{mL}$ microcentrifuge tube and $400 \mu \mathrm{l}$ of reagent was added to dissolve the paraffin; the sample was incubated for 3 minutes at $60{ }^{\circ} \mathrm{C}$, vortexed and allowed to temper at room temperature. $100 \mu \mathrm{L}$ of $\mathrm{FL}$ buffer were added and centrifuged at $11,000 \times \mathrm{g}$ for 1 minute, with generation of two phases: lower-aqueous (tissue and buffer) and higher-organic (paraffin). $10 \mu \mathrm{L}$ proteinase $\mathrm{K}$ were added to the lower phase and mixed with pipette; then, it was incubated at room temperature for 3 hours. $100 \mu \mathrm{L}$ of Decrosslink ${ }^{\circledR}$ buffer were added and it was incubated at $90{ }^{\circ} \mathrm{C}$ for 30 minutes to remove the material interspersed in the isolated DNA. Once the process was finished, it was left to stand at room temperature for 
2 minutes. $200 \mu \mathrm{L}$ of ethanol (96-100\%) were added and vortexed (2-5 seconds), centrifuged for $30 \mathrm{sec}-$ onds at $11,000 \mathrm{xg}$ to separate the phases. The aqueous phase was pipetted and placed on the NS-FFPE column installed in a 2-mL collecting tube. The DNA present in the sample binds to the silica membrane of the column. Salts, metabolites and macromolecular cellular components were removed with two wash and centrifugation assays ( $400 \mu \mathrm{L}$ buffer B5, 2,000 $\mathrm{x}$ $\mathrm{g}$ for 30 seconds and $11,000 \mathrm{x}$ for 30 seconds). The collector tube used was removed and the column was placed in a new microcentrifuge tube. $20 \mu \mathrm{L}$ of $\mathrm{BE}$ buffer was placed at the center of the silica membrane and centrifuged for 30 seconds at $11,000 \times \mathrm{g}$, whereby a final DNA eluate was obtained (15-20 $\mu \mathrm{L})$, whose purity and concentration were analyzed by spectrophotometry.

\section{Viral DNA amplification}

The viral genome was analyzed using the reverse linear hybridization INNO-LiPA ${ }^{\circledR}$ HPV Genotyping Extra kit (Innogenetics, Belgium). A Master Mix was prepared on ice, containing $37.7 \mu \mathrm{L}$ of AMP MIX (biotinylated primers, deoxyribonucleotides, $\mathrm{MgCl}_{2}$ and $0.05 \% \mathrm{NaN}_{3}$ as preservative). $2.3 \mu \mathrm{L}$ of ENZ MIX (AmpliTaq Gold ${ }^{\circledR}$ ) were added, and this mixture was then added $10 \mu \mathrm{L}$ of the final DNA eluate. As DNA positive control, $10 \mu \mathrm{L}$ of the control provided for the kit were used, which was positive as hybridization internal control in all experiments and corresponds to HPV-6. As DNA negative control, $10 \mu \mathrm{L}$ of DNA-free distilled $\mathrm{H}_{2} \mathrm{O}$ were used in all experiments

\section{Detection and typing}

- Hybridization: $10 \mu \mathrm{L}$ of the amplified biotinylated product were used for hybridization in the strip, which were mixed with $10 \mu \mathrm{L}$ of denaturation solution in the hybridization independent channels placed on a plastic plate for 5 minutes at room temperature. $10 \mu \mathrm{L}$ of the biotinylated amplified product were mixed with $10 \mu \mathrm{L}$ of denaturation solution during 5 minutes at room temperature at each independent hybridization channel of the plastic plate provided by the manufacturer. Then, $2 \mathrm{~mL}$ of hybridization solution were added to each channel and mixed by pipetting. One previouslymarked test strip was placed at its respective channel. To finish this stage, the channels were placed in a water bath at $49{ }^{\circ} \mathrm{C}$ with agitation (approximately 80 agitations per minute) for 60 minutes.

- Washing: after hybridization, the plastic plate was held at an angle that allowed the fluid contained in each channel to be aspired with a pipette. Then, $2 \mathrm{~mL}$ of the washing solution, preheated at $37^{\circ} \mathrm{C}$, were added to each channel and agitated for 10 to 20 seconds at room temperature. This step was repeated three times, with the last one being left to incubate in a water bath at $49{ }^{\circ} \mathrm{C}$ under agitation for 30 minutes.

- Coloring development: all subsequent incubations were carried out at a temperature ranging from 20 to $25{ }^{\circ} \mathrm{C}$ in agitation. Each strip was washed twice for 1 minute using $2 \mathrm{~mL}$ of the rinse solution. Then, $2 \mathrm{~mL}$ of the conjugated were added to each channel and incubated for 30 minutes with agitation. After aspirating the fluid of each channel, each strip was washed twice using the rinse solution under agitation for 1 minute, and then the same step was carried out using $2 \mathrm{ml}$ of substrate buffer. Then, the buffer was aspirated to then add $2 \mathrm{~mL}$ of substrate solution to each channel, leaving them in incubation for $30 \mathrm{~min}$ utes under agitation. This last step provided coloration of the lines that displayed hybridization. The reaction was stopped by adding $2 \mathrm{~mL}$ of distilled water under agitation for 3 minutes.

- Interpretation of results: the hybridization strips they have three controls, which consist of a conjugate control band, a human DNA control band and two HPV control bands. Subsequently, the reading of the number of reactive bands resulting from the hybridization process between amplification products and the immobilized probes on the strip was carried out. The band pattern of each strip was compared with the interpretation table provided by the manufacturer to determine the genotype(s) present in each sample.

\section{Statistical analysis}

For analysis of the results, absolute frequencies, percentages, means and standard deviations were used. In addition, the chi-square test, Fisher's exact probability test and Student's t-test were used for independent samples. The analysis was performed with the SPSS package v. 20.0 for Windows, and a $p$-value $<0.05$ was considered significant. 


\section{Ethical aspects}

The present study adheres to the ethical principles of the Declaration of Helsinki and its subsequent developments, and to the Principles of Good Clinical Practice. In addition, it is in accordance with the standards established in the General Statute of Health and with institutional health research regulations. The protocol was authorized by the National Commission of Scientific Research of the institution where the study was conducted with registration No. R-2014-785-055. Obtaining informed consent was not required since only patient records were reviewed.

\section{Results}

Hundred and twelve laryngeal tissue samples corresponding to 112 patients with laryngeal cancer from a tertiary care medical unit of northeastern Mexico were included. These samples corresponded to 72 slides and paraffin blocks obtained by biopsy (64.3\%) and 40 slides and paraffin blocks obtained by laryngectomy $(35.7 \%)$. Five patients were females $(4.5 \%)$ and 107 were males (95.5\%). Mean age was $65.3 \pm 10.1$ years. Most patients $(n=108)$ had a smoking history $(96.4 \%)$, and few $(n=9)$ had a positive history of alcoholism (8.0\%). Tumors most common location was glottic, in 65 patients $(58 \%)$, followed by transglottic in $26(23.2 \%)$ and supraglottic in $17(15.2 \%)$. The most common histological diagnosis was moderately-differentiated keratinizing squamous cell carcinoma in 96 patients $(85.7 \%)$, followed by well-differentiated invasive squamous cell carcinoma in 11 (9.8\%), moderately-differentiated non-keratinizing squamous cell carcinoma in 3 $(2.7 \%)$ and poorly-differentiated squamous cell carcinoma in $2(1.8 \%)$ (Tables 1 and 2$)$.

HPV infection was detected in 60 of the 112 samples (53.5\%). Most common genotype was HPV-11 in 51 samples (45.5\%), followed by HPV-52 in 27 (24.1\%), HPV-16 in $9(8.0 \%)$ and HPV-45 in $3(2.6 \%)$. Coinfection with more than one genotype was detected in 31 samples $(27.6 \%)$, with the most common co-infections being with HPV-11 and HPV-52 (Table 2). There was no significant difference between patients with and without HPV infection in terms of distribution by age, gender, tumor location and histopathological diagnosis, or with regard to previous history of smoking or alcoholism $(p>0.05)$ (Table 1).
Table 1. Clinical and histopathological characteristics of $\mathbf{1 1 2}$ Northeastern Mexico patients with laryngeal cancer classified according to HPV identification in laryngeal tissue

\begin{tabular}{|c|c|c|c|c|}
\hline & $\begin{array}{c}\text { Total } \\
(\mathrm{n}=112)\end{array}$ & $\begin{array}{l}\text { With HVP } \\
(n=60)\end{array}$ & $\begin{array}{l}\text { Without HVP } \\
\quad(n=52)\end{array}$ & p \\
\hline Age (years) ${ }^{*}$ & $65.3 \pm 10.1$ & $65.5 \pm 8.9$ & $64.9 \pm 11.4$ & 0.756 \\
\hline Gender & & & & 0.432 \\
\hline Males & 107 (95.5\%) & 58 (54.2\%) & $49(45.8 \%)$ & \\
\hline Females & $5(4.5 \%)$ & $2(40 \%)$ & $3(60 \%)$ & \\
\hline Sample & & & & 0.022 \\
\hline Biopsy & $72(64.3 \%)$ & $33(45.8 \%)$ & $39(54.2 \%)$ & \\
\hline Laryngectomy & $40(35.7 \%)$ & $27(67.5 \%)$ & $13(32.5 \%)$ & \\
\hline Location & & & & 0.556 \\
\hline Glottic & $65(58.0 \%)$ & $32(49.2 \%)$ & 33 (50.8\%) & \\
\hline Subglottic & $4(3.6 \%)$ & $3(75.0 \%)$ & $1(25.0 \%)$ & \\
\hline Supraglottic & $17(15.2 \%)$ & $11(64.7 \%)$ & $6(35.3 \%)$ & \\
\hline Transglottic & $26(23.2 \%)$ & $14(53.8 \%)$ & $12(46.2 \%)$ & \\
\hline $\begin{array}{l}\text { Histopathological } \\
\text { diagnosis }\end{array}$ & & & & 0.406 \\
\hline WDISCC & $11(9.8 \%)$ & $5(45.5 \%)$ & $6(54.5 \%)$ & \\
\hline MDNKSCC & $96(85.7 \%)$ & $53(55.2 \%)$ & $43(44.8 \%)$ & \\
\hline MDKSCC & $3(2.7 \%)$ & $2(66.7 \%)$ & $1(33.3 \%)$ & \\
\hline PDSCC & $2(1.8 \%)$ & $0(0 \%)$ & $2(100 \%)$ & \\
\hline Smoking & & & & 0.365 \\
\hline Yes & $108(96.4 \%)$ & 57 (52.8\%) & $51(47.2 \%)$ & \\
\hline No & $4(3.6 \%)$ & $3(75 \%)$ & $1(25 \%)$ & \\
\hline Alcoholism & & & & 0.120 \\
\hline Yes & $9(8.0 \%)$ & $7(77.8 \%)$ & $2(22.2 \%)$ & \\
\hline No & $103(92.0 \%)$ & 53 (51.5\%) & $50(48.5 \%)$ & \\
\hline
\end{tabular}

${ }^{*}$ At the time of biopsy collection or laryngectomy.

Values presented as mean \pm standard deviation or absolute frequency (percentage) WDISCC: well-differentiated invasive squamous cell carcinoma; MDNKSCC: moderately-differentiated non-keratinizing squamous cell carcinoma; MDKSCC: moderately-differentiated keratinizing squamous cell carcinoma; PDSCC: poorlydifferentiated squamous cell carcinoma.

\section{Discussion}

Laryngeal cancer accounts for $21.7 \%$ of upper aerodigestive tract malignant neoplasms, and has as main risk factors smoking and alcoholism; information in international literature is scarce with regard to HPV infection as possible risk factor ${ }^{1-4}$. The presence of HPV in larynx cancer has been reported in 0 to $80 \%$ of cases $^{9-17}$. In Mexico, there are three published studies related to the subject: in the first of them, 16 of 32 samples of patients with laryngeal cancer were positive for HPV $(50 \%)$, in the second, HPV was demonstrated in 4 of 16 samples of patients with laryngeal cancer (25\%), and in the third one, only in 2 of 45 samples of laryngeal cancer patients (4.4\%) could HPV be detected ${ }^{9,18,19}$.The present study evaluated HPV prevalence and genotypes in samples of laryngeal tissue of patients with laryngeal cancer who were 
Cirugía y Cirujanos. 2018;86(6)

Table 2. Clinical and histopathological characteristics and HPV genotype, in 60 patients with laryngeal cancer of northeastern Mexico

\begin{tabular}{|c|c|c|c|c|c|c|c|c|}
\hline Patient & Age & Gender & Sample & Localization & Histopathological diagnosis & Smoking & Alcoholism & VPH genotype(s) \\
\hline 1 & 54 & $\mathrm{~F}$ & Biopsy & Glottic & MDKSCC & Yes & No & 11 \\
\hline 2 & 66 & M & Biopsy & Supraglottic & WDISCC & Yes & Yes & 11 \\
\hline 3 & 66 & M & Biopsy & Glottic & MDKSCC & Yes & No & 11 \\
\hline 4 & 54 & M & Biopsy & Glottic & MDKSCC & Yes & No & 11,16 \\
\hline 5 & 64 & M & Laryngectomy & Transglottic & MDKSCC & Yes & No & 11 \\
\hline 6 & 64 & M & Biopsy & Glottic & MDKSCC & Yes & No & $11,16,40,82$ \\
\hline 7 & 70 & M & Laryngectomy & Glottic & MDKSCC & Yes & No & 11 \\
\hline 8 & 52 & M & Biopsy & Glottic & MDKSCC & Yes & No & 11 \\
\hline 9 & 67 & M & Biopsy & Supraglottic & MDKSCC & Yes & No & 11 \\
\hline 10 & 67 & M & Biopsy & Glottic & MDKSCC & Yes & Yes & 11 \\
\hline 11 & 58 & M & Laryngectomy & Subglottic & MDKSCC & Yes & No & 11 \\
\hline 12 & 71 & M & Laryngectomy & Transglottic & MDKSCC & Yes & No & 11 \\
\hline 13 & 59 & M & Biopsy & Glottic & MDNKSCC & Yes & Yes & 16 \\
\hline 14 & 49 & M & Laryngectomy & Transglottic & WDISCC & Yes & No & 11 \\
\hline 15 & 66 & M & Biopsy & Glottic & MDKSCC & Yes & No & 11 \\
\hline 16 & 65 & M & Laryngectomy & Glottic & MDKSCC & Yes & Yes & 11 \\
\hline 17 & 67 & M & Biopsy & Supraglottic & MDKSCC & Yes & No & 11 \\
\hline 18 & 76 & M & Biopsy & Supraglottic & MDKSCC & Yes & No & 11 \\
\hline 19 & 80 & M & Biopsy & Glottic & MDKSCC & No & No & 11 \\
\hline 20 & 61 & M & Laryngectomy & Subglottic & MDKSCC & Yes & Yes & 52 \\
\hline 21 & 53 & M & Laryngectomy & Supraglottic & MDKSCC & Yes & No & 16 \\
\hline 22 & 61 & M & Biopsy & Supraglottic & MDKSCC & Yes & No & 52 \\
\hline 23 & 63 & M & Biopsy & Glottic & MDKSCC & Yes & No & 16 \\
\hline 24 & 68 & M & Biopsy & Supraglottic & MDKSCC & Yes & No & 11,16 \\
\hline 25 & 79 & M & Biopsy & Supraglottic & MDKSCC & Yes & No & 11 \\
\hline 26 & 81 & M & Biopsy & Glottic & MDKSCC & Yes & No & 11,52 \\
\hline 27 & 67 & M & Biopsy & Glottic & MDKSCC & Yes & No & 11,16 \\
\hline 28 & 71 & M & Laryngectomy & Transglottic & MDKSCC & Yes & No & $6,11,52$ \\
\hline 29 & 80 & M & Biopsy & Supraglottic & MDKSCC & Yes & No & 6,11 \\
\hline 30 & 63 & M & Laryngectomy & Transglottic & MDKSCC & Yes & No & 11,52 \\
\hline 31 & 68 & M & Laryngectomy & Glottic & MDKSCC & No & Yes & $11,45,52$ \\
\hline 32 & 83 & M & Biopsy & Supraglottic & MDKSCC & Yes & No & $6,11,52$ \\
\hline 33 & 66 & M & Biopsy & Glottic & MDKSCC & Yes & No & 52 \\
\hline 34 & 60 & M & Laryngectomy & Transglottic & MDKSCC & Yes & No & 11,52 \\
\hline 35 & 67 & M & Biopsy & Glottic & WDISCC & Yes & No & 45 \\
\hline 36 & 69 & $\mathrm{M}$ & Biopsy & Glottic & MDKSCC & Yes & No & $6,11,52$ \\
\hline
\end{tabular}


Table 2. Clinical and histopathological characteristics and HPV genotype, in 60 patients with laryngeal cancer of northeastern Mexico (Continued)

\begin{tabular}{|c|c|c|c|c|c|c|c|c|}
\hline Patient & Age & Gender & Sample & Localization & Histopathological diagnosis & Smoking & Alcoholism & VPH genotype(s) \\
\hline 37 & 60 & M & Laryngectomy & Glottic & MDKSCC & Yes & No & 11,45 \\
\hline 38 & 72 & $\mathrm{~F}$ & Biopsy & Glottic & WDISCC & Yes & No & 11,52 \\
\hline 39 & 72 & M & Laryngectomy & Glottic & MDKSCC & Yes & No & 11,52 \\
\hline 40 & 51 & M & Laryngectomy & Transglottic & MDKSCC & Yes & No & 52 \\
\hline 41 & 61 & M & Biopsy & Glottic & MDKSCC & Yes & No & 11,52 \\
\hline 42 & 78 & M & Biopsy & Glottic & MDKSCC & Yes & Yes & 11,16 \\
\hline 43 & 61 & M & Laryngectomy & Transglottic & MDKSCC & Yes & No & $6,11,52$ \\
\hline 44 & 56 & M & Laryngectomy & Subglottic & MDKSCC & Yes & No & 11,52 \\
\hline 45 & 62 & M & Biopsy & Glottic & MDKSCC & Yes & No & 11,52 \\
\hline 46 & 79 & M & Biopsy & Glottic & MDKSCC & Yes & No & 11,52 \\
\hline 47 & 84 & M & Laryngectomy & Glottic & MDKSCC & Yes & No & $6,11,52$ \\
\hline 48 & 55 & M & Biopsy & Glottic & MDKSCC & Yes & No & $6,11,52$ \\
\hline 49 & 65 & M & Laryngectomy & Transglottic & MDKSCC & Yes & Yes & $11,16,52$ \\
\hline 50 & 58 & M & Laryngectomy & Transglottic & MDKSCC & Yes & No & 11,52 \\
\hline 51 & 72 & M & Laryngectomy & Transglottic & MDKSCC & No & No & 11,52 \\
\hline 52 & 74 & M & Laryngectomy & Transglottic & MDKSCC & Yes & No & 11,52 \\
\hline 53 & 67 & M & Laryngectomy & Glottic & MDKSCC & Yes & No & 52 \\
\hline 54 & 72 & M & Laryngectomy & Supraglottic & MDKSCC & Yes & No & 11 \\
\hline 55 & 64 & M & Laryngectomy & Glottic & MDKSCC & Yes & No & 11 \\
\hline 56 & 44 & M & Laryngectomy & Transglottic & MDKSCC & Yes & No & 11 \\
\hline 57 & 62 & M & Biopsy & Supraglottic & MDKSCC & Yes & No & 11,52 \\
\hline 58 & 70 & M & Biopsy & Glottic & MDNKSCC & Yes & No & 11,52 \\
\hline 59 & 49 & M & Biopsy & Glottic & MDKSCC & Yes & No & 11,52 \\
\hline 60 & 72 & M & Laryngectomy & Glottic & MDKSCC & Yes & No & 11,52 \\
\hline
\end{tabular}

F: female; M: male; MDKSCC: moderately differentiated keratinizing squamous cell carcinoma; MDNKSCC: moderately differentiated non-keratinizing squamous cell carcinoma; WDISCC: well differentiated invasive squamous cell carcinoma:

provided care in a tertiary care medical unit of northeastern Mexico.

Patient age of presentation was around 65 years, which is consistent with descriptions in international literature, since larynx cancer occurs more commonly in the sixth decade of life ${ }^{1,2}$. No cases of pediatric age patients with larynx cancer were found. To date, there are about 80 pediatric patients with larynx cancer reported since 1868, some of them related to HPV infection $^{20-24}$. In this study, patients of the male gender predominated, which is consistent with previously described observations, since larynx cancer especially affects men ${ }^{1,2}$. In 2009, Joos et al. ${ }^{22}$ reported a predominance of the male gender of up to $80 \%$; however, this relationship is different in younger population, in whom only $60 \%$ of male predominance has been reported. In recent years, a change has been observed in laryngeal cancer behavior pattern, including an increase in its frequency in young people, women and tobacco or alcohol non-consumers ${ }^{22,25}$.

Up to $96.4 \%$ of patients with laryngeal cancer of the present study had a history of smoking, which is higher than the rates reported in previous studies. In the United Kingdom, there is a history of smoking in up 
to $79 \%$ of larynx cancer patients ${ }^{26}$. People with a smoking history have a relative risk up to 8.3-fold higher for developing larynx cancer in comparison with never smokers ${ }^{27}$.

The frequency of alcoholism in the sample of this study was $8 \%$. Alcoholism increases up to four times the risk for developing larynx cancer when alcohol consumption is $\geq 25$ ounces per month in comparison with non-alcoholic people ${ }^{28}$. Additionally, a positive relationship has been identified between alcohol consumption and the predominantly supraglottic location of larynx neoplasims ${ }^{29}$. In the laryngeal samples with HPV infection of the present study, the most common location was glottic, followed by transglottic and supraglottic, a location order similar to that reported in a recent systematic review. ${ }^{13}$ The low HPV prevalence in supraglottic tumors is explainable by the fact that these neoplasms have a more important association with alcohol consumption ${ }^{29}$.

In this study, HPV DNA was detected in 53\% of analyzed samples. Hobbs et al. ${ }^{8}$ assessed the relationship between HPV and head and neck cancer, demonstrating a strong association with cancers located in the tonsils (odds ratio [OR]: 15.1; 95\% Confidence Interval [CI]: 6.8-33.7), an intermediate risk for the rest of the oropharynx (OR: 4.3; 95\% Cl: 2.1-8.9) and a very weak risk for the oral cavity (OR: $2.0 ; 95 \%$ $\mathrm{Cl}: 1.2-3.4)$ and the larynx (OR: 2.0; 95\% Cl: 1.0-4.2). The prevalence of HPV infection in larynx cancer is variable, ranging from 0 to $80 \%{ }^{9-17}$. In Mexico, there are only three studies reporting the prevalence of HPV infection in larynx cancer: one performed on a sample of 16 patients with a prevalence of $25 \%$, another in 32 patients with a prevalence of $50 \%$, and another that assessed 45 patients, with a prevalence of $4.4 \% \%^{9,18,19}$. Therefore, the prevalence of HPV infection in larynx cancer detected in this series is the highest reported in Mexico. It should be noted that in this study there was a large number of samples available than in previous studies conducted in Mexico ${ }^{9,18,19}$. The wide variability in HPV prevalence between studies could be due to bias in sample selection, differences in the techniques used for HPV detection, different anatomical sampling sites, poor quality of samples or individual genetic, ethnic, geographic and cultural differences ${ }^{12,13}$.

The most common HPV genotype in this study was 11 , in $45 \%$ of the samples, followed by 52 in $24 \%$ and 16 in $8.0 \%$. Other detected genotypes were $6,45,82$ and 40 . Genotypes 6, 11 and 40 are of low oncogenic risk, while genotypes $16,45,52$ and 82 are of high oncogenic risk ${ }^{5}$. The low prevalence of HPV-16 detected in this series is remarkable since, in other studies, it has been the genotype that is most associated with the pathogenesis of laryngeal carcinoma ${ }^{6-9}$. In 2016, Villagómez-Ortiz et al..$^{19}$ reported the HPV-11 genotype in 2 of 45 studied samples. This genotype shows a more aggressive behavior in patients with recurrent laryngeal papillomatosis, who require a larger number of surgical resections per year ${ }^{30}$. There are cases that describe the transformation of recurrent laryngeal papillomatosis into squamous cell carcino$\mathrm{ma}$ in the presence of infection with low-risk genotypes, such as 6 and $11^{31}$.

In this study, coinfection was found with more than one genotype in 31 samples (27.6\%), and the most common coinfection was with HPV-11 and HPV-52, which are genotypes of low and high oncogenic risk, respectively. Coinfection with more than one genotype was reported in two of the 16 samples examined in one of the previous studies conducted in Mexico, and it was with low- and high-risk genotypes ${ }^{18}$. This suggests that, in some cases of laryngeal cancer, HPV could be involved regardless of its oncogenic risk, or that both genotype viral groups could act synergistically ${ }^{18}$. In this study, one case of coinfection with genotypes 11, 16, 40 and 82 was identified; in international literature there are only reports of two cases of laryngeal cancer related to HPV-82, one of them with coinfection with HPV-7332,33.

Among the possible clinical implications of HPV infection as a causative agent of larynx cancer, the genotypes present in this malignancy would be expected to resemble those found in cervical lesions, since orogenital contamination is the transmission route proposed as the more common. Therefore, the role of the HPV vaccines currently available in the market in the prevention of head and neck cancers, including laryngeal cancer, is still unknown ${ }^{12}$. Furthermore, HPV infection in larynx cancer opens the possibility to new therapies with HPV-infected cells by as a target ${ }^{12}$. On the other hand, knowing the prognosis of these patients is a matter of interest, given that there are reports of a greater therapeutic response and survival in patients with oropharyngeal cancer associated with HPV infection ${ }^{34-36}$.

\section{Conclusions}

The results of the present study show a prevalence of HPV infection of $53.5 \%$ in samples of laryngeal tissue of patients with laryngeal cancer, with coinfection 
with more than one genotype in $27.6 \%$ of the samples. The most common genotype was HPV-11, a low-risk type, followed by HPV-52, a high-risk oncogenic genotype, but infection with high-risk genotypes was detected in $34.8 \%$ of the samples. A positive result for HPV DNA amplified by Polymerase Chain Reaction (PCR) only demonstrates its presence and not necessarily implies its role in carcinogenesis. The conduction of epidemiological studies at a larger scale is required, not only with larger samples, but also including simultaneous assessment of histopathological, immunohistochemical findings, of in situ hybridization and DNA amplification by PCR, in order to know the true prevalence of HPV infection in laryngeal mucosa and larynx cancer. This would also allow having more solid evidence of its true oncogenic potential in the larynx, as well as its possible interaction with well-established risk factors, such as alcohol and tobacco consumption. The prognosis of patients with laryngeal cancer associated with HPV infection, as well as the long-term impact of currently available vaccines on the development of this disease, remain to be established.

\section{Ethical disclosure}

Protection of people and animals. The authors declare that no experiments were performed on humans or animals for this investigation.

Confidentiality of data. The authors declare that they have followed the protocols of their work center on the publication of patient data.

Right to privacy and informed consent. The authors declare that no patient data appear in this article.

\section{Conflict of interests}

The authors declare that they have no conflicts of interests.

\section{Funding}

The present study was financed through a fund approved by Programa de Apoyo a la Investigación Científica y Tecnológica (PAICYT 2015, with registration No. SA156-15).

\section{Acknowledgements}

Special thanks to Clin. Biochem. Silvia Margarita García Herrera, from Medicina Diagnóstica de
Monterrey, Mexico, for her assistance in the histotechnology process for obtaining the samples by punch (biopsy punch). Dr. Gerardo C. Palacios was supported by a Research Excellence Scholarship granted by Fundación IMSS, A.C.

\section{References}

1. Siegel RL, Miller KD, Jemal A. Cancer statistics, 2016. CA Cancer J Clin. 2016;66:7-30.

2. Flint PW. Epidemiology. En: Armstrong WB, Vokes DE, Maisel RH, editors. Cummings Otolaryngology - Head and neck surgery. Philadelphia: Mosby Elsevier; 2010. p. 107.

3. Durán de Alba LM, Roa Castro FM. Risk factors for developing laryngea cancer in adult population at the Hospital Español in Mexico city. Acta Otorrinolaringol Esp. 2008;59:367-70.

4. Gorgoulis V, Zacharatos P, Kotsinas A, Kyroudi A, Rassidakis AN, Ikonomopuulos JA, et al. Human papillomavirus (HPV) is possibly involved in laryngeal but not in lung carcinogenesis. Hum Pathol. 1999;30:274-83.

5. Muñoz N, Bosch FX, de Sanjosé S, Herrero R, Castellsaqué X, Shah KV, et al. Epidemiologic classification of human papillomavirus types associated with cervical cancer. N Engl J Med. 2003;348:518-27.

6. Morshed K, Stenzel A, Szymański M, Rózyńska K, Siwiec H, Gołabek W, et al. Detection of human papillomavirus type 16 and 18 in laryngeal cancer using PCR. Otolaryngol Pol. 2001;55:29-33.

7. Liu B, Lu Z, Wang P, Basang Z, Rao X. Prevalence of high-risk human papillomavirus types (HPV-16, HPV-18) and their physical status in primary laryngeal squamous cell carcinoma. Neoplasma. 2010; 57:594-600.

8. Hobbs CG, Sterne JA, Bailey M, Heyderman RS, Birchall MA, Thomas SJ. Human papillomavirus and head and neck cancer: a systematic review and meta-analysis. Clin Otolaryngol. 2006;31:259-66.

9. Gallegos-Hernández J, Paredes-Hernández E, Flores-Díaz R, Minauro-Muñoz G, Apresa-García T, Hernández-Hernández DM. Human papillomavirus: association with head and neck cancer. Cir Cir. 2007;75:151-5.

10. Badaracco G, Rizzo C, Mafera B, Pichi B, Giannarelli D, Rahimi SS, et al. Molecular analyses and prognostic relevance of HPV in head and neck tumours. Oncol Rep. 2007:17:931-9.

11. Gillison M, Koch W, Capone RB, Spafford M, Westra WH, Wu L, et al. Evidence for a causal association between human papillomavirus and a subset of head and neck cancers. J Natl Cancer Inst. 2000;92:709-12.

12. Torrente MC, Rodrigo JP, Haigentz M Jr, Dikkers FG, Rinaldo A, Takes RP, et al. Human papillomavirus infections in laryngeal cancer. Head Neck. 2011;33:581-6.

13. Li X, Gao L, Li H, Gao J, Yang Y, Zhou F, et al. Human papillomavirus infection and laryngeal cancer risk: a systematic review and meta-analysis. J Infect Dis. 2013;207:479-88.

14. Morshed K. Association between human papillomavirus infection and laryngeal squamous cell carcinoma. J Med Virol. 2010;82:1017-23.

15. Baumann JL, Cohen S, Evjen AN, Law JH, Vadivelu S, Attia A, et al. Human papillomavirus in early laryngeal carcinoma. Laryngoscope. 2009;119:1531-7

16. Gungor A, Cincik H, Baloglu H, Cekin E, Dogru S, Dursun E. Human papilloma virus prevalence in laryngeal squamous cell carcinoma. J Laryngol Otol. 2007;121:772-4.

17. Kreimer AR, Clifford GM, Boyle P, Franceschi S. Human papillomavirus types in head and neck squamous cell carcinomas worldwide: a systematic review. Cancer Epidemiol Biomarkers Prev. 2005:14:467-75.

18. Manjarrez ME, Ocadiz R, Valle L, Pacheco C, Marroquín A, De la Torre C, et al. Detection of human papillomavirus and relevant tumor suppressors and oncoproteins in laryngeal tumors. Clin Cancer Res. 2006;23:6947-51.

19. Villagómez-Ortiz VJ, Paz-Delgadillo DE, Marino-Martínez I, Ceseñas-Falcón LA, Sandoval-de la Fuente A, Reyes-Escobedo A. Prevalencia de infección por virus del papiloma humano en carcinoma espinocelular de cavidad oral, orofaringe y laringe. Cir Cir. 2016; 84:363-8.

20. Balakrishnan R, Chowdhury Q, Hussain M, Hassan M, Haque N, Sharmeen $\mathrm{F}$, et al. Early glottic squamous cell carcinoma in a 16 year old: case report, review of literature and pediatric head and neck radiotherapy guidelines. Case Rep Oncol. 2015;8:363-8.

21. McDermott A, Raj P, Glaholm J, Pearman K, Macnamara M. De novo laryngeal carcinoma in childhood. J Laryngol Otol. 2000;114:293-5.

22. Joos B, Joos N, Bumpous J, Burns C, French CA, Farghaly H. Laryngeal squamous cell carcinoma in a 13 year old child associated with human papilloma viruses 16 and 18: a case report and review of the literature. Head Neck Pathol. 2009;3:37-41.

23. Gindhart TD, Johnston WH, Chism SE, Dedo HH. Carcinoma of the larynx in childhood. Cancer. 1980;46:1683-7. 
24. Rastogi M, Srivastava M, Bhatt MLB, Srivastava K, Bhatia N. Laryngeal carcinoma in a 13-year-old child. Oral Oncol Extra. 2005;41:207-10.

25. León X, Rinaldo A, Saffiotti U, Ferlito A. Laryngeal cancer in non-smoking and non-drinking patients. Acta Otolaryngol. 2004:124:664-9.

26. Parkin DM, Boyd L, Walker LC. The fraction of cancer attributable to lifestyle and environmental factors in the UK in 2010. Br J Cancer. 2011;105:S77-81.

27. Wyss A, Hashibe M, Chuang SC, Lee YC, Zhang ZF, Yu GP, et al. Cigarette, cigar, and pipe smoking and the risk of head and neck cancers: pooled analysis in the International Head and Neck Cancer Epidemiology Consortium. Am J Epidemiol. 2013;178:679-90.

28. Altieri A, Garavello W, Bosseti C, Gallus S, La Vecchia C. Alcohol consumption and risk of laryngeal cancer. Oral Oncol. 2005;41:956-65.

29. La Vecchia C, Zhang ZF, Altieri A. Alcohol and laryngeal cancer: an update. Eur J Cancer Prev. 2008:17:116-24.

30. Gerein V, Rastorguev E, Gerein J, Draf W, Schirren J. Incidence, age at onset, and potential reasons of malignant transformation in recurrent respiratory papilomatosis patients: 20 years of experience. Otolaryngol Head Neck Surg. 2005;132:392-4.
31. Jeong WJ, Park SW, Shin M, Lee YJ, Jeon YK, Jung YH, et al. Presence of HPV type 6 in dysplasia and carcinoma arising from recurrent respiratory papillomatosis. Head Neck. 2009;31:1095-101.

32. Si-Mohamed A, Badoual C, Hans S, Péré H, Tartour E, Brasnu D. An unusual human papillomavirus type 82 detection in laryngeal squamous cell carcinoma: case report and review of literature. J Exp Clin Virol. 2012;54:190-3.

33. Pannone G, Sanguedolce F, Santoro A, Fierro P, Panetti M, Fierro D, et al. Detection of novel human papillomavirus type 82 in laryngeal cancer: case report. Auris Nasus Larynx. 2010;37:648-50.

34. Ang KK, Harris J, Wheeler R, Weber R, Rosenthal DI, Nguyen-Tân PF, et al. Human papillomavirus and survival of patients with oropharyngeal cancer. N Engl J Med. 2010;363:24-35.

35. Fakhry C, Westra WH, Li S, Cmelak A, Ridge JA, Pinto H, et al. Improved survival of patients with human papillomavirus-positive head and neck squamous cell carcinoma in a prospective clinical trial. J Natl Cancer Inst. 2008;100:261-9.

36. Ragin CC, Taioli E. Survival of squamous cell carcinoma of the head and neck in relation to human papillomavirus infection: review and meta-analysis. Int J Cancer. 2007;121:1813-20. 